\title{
Konstrukcja prawna prezydentury w okresie działania Krajowej Rady Narodowej w latach 1944-1947
}

I. Zajęcie w 1944 r. przez wojska radzieckie części okupowanego przez Niemców terytorium Polski wytworzyło nową sytuację polityczną w kraju. Dla rodzimych komunistów, działających dotąd w konspiracji, był to jasny sygnał, że przyszedł czas, by pod sowieckimi auspicjami przystąpić do organizowania struktur nowego państwa, niezależnego od ośrodka londyńskiego. Na porządku dziennym stanęła kwestia wypracowania zrębów ustroju konstytucyjnego Polski Ludowej. Zagadnienie to stało się jednym z priorytetów rewolucyjnej władzy, która już 21 lipca 1944 r., zaraz po zajęciu przez Armię Czerwoną Lublina, ogłosiła osławiony Manifest Lipcowy. W dość zdawkowy sposób dokument ten zakreślał ramy ustrojowe komunistycznej Polski, odwołując się do postanowień obowiązującej w okresie międzywojnia Konstytucji marcowej z 1921 r. w jej pierwotnym brzmieniu. Co charakterystyczne, nie była to pełna recepcja przepisów zawartych w tejże Konstytucji, a jedynie bliżej niesprecyzowane nawiązanie do jej ,podstawowych założeń". Takie postawienie sprawy stwarzało po stronie komunistycznego prawodawcy szerokie pole swobody decyzyjnej w określaniu przyszłych form ustrojowych państwa. $\mathrm{W}$ istocie, jak pokazała historia, do nowego porządku konstytucyjnego przeniósł on tylko niektóre rozwiązania międzywojenne, wzbogacając je jednocześnie o konstrukcje prawne zaczerpnięte z wzorów sowieckich.

Znamienną cechą stworzonego w pierwszym etapie systemu władzy państwowej była tymczasowość wszystkich postanowień. Manifest Lipcowy nie uważał Konstytucji marcowej za trwałą podstawę ustroju państwa. Według zawartych w nim dyspozycji, miała ona obowiązywać do chwili ukonstytuowania się wybranego demokratycznie przez Naród Sejmu. Tak zakreślony horyzont czasowy oznaczał, że w istocie rzeczy wyartykułowana w Manifeście koncepcja ustrojowa nadawała najwyższym władzom państwowym status instytucji prowizorycznych. Tymczasowy charakter utrzymano, gdy idzie 
o Krajową Radę Narodową ${ }^{1}$, organ utworzony jeszcze w warunkach konspiracji na przełomie roku 1943 i 1944, spełniający rolę kadłubowego parlamentu. Manifest PKWN stwierdzał wprost: „Dlatego Krajowa Rada Narodowa, tymczasowy parlament narodu polskiego, powołała Polski Komitet Wyzwolenia Narodowego [...]". Tymczasowy był także powstały w dniu 21 lipca 1944 r. Polski Komitet Wyzwolenia Narodowego, pomyślany jako organ władzy wykonawczej - rząd Polski Ludowej. Kwestię tę expressis verbis stawiała ustawa z 21 lipca 1947 r. o utworzeniu Polskiego Komitetu Wyzwolenia Narodowego, głosząca jednoznacznie: „Rozpoczęły się decydujące walki o wypędzenie z Polski niemieckich najeźdźców. W obliczu tych historycznych wydarzeń Krajowa Rada Narodowa powołuje Polski Komitet Wyzwolenia Narodowego jako tymczasową władzę wykonawczą dla kierowania [...]". Walor tymczasowości przypisano wreszcie instytucji jednoosobowej głowy państwa, przywróconej formalnie do porządku konstytucyjnego na mocy ustawy z 11 września o organizacji i zakresie działania rad narodowych oraz ustawy uchwalonej w tej samej dacie o kompetencji Przewodniczącego (Prezydenta) Krajowej Rady Narodowej ${ }^{2}$.

W literaturze prawnoustrojowej czasu powojennego podkreśla się, że w okresie do 11 września 1944 r. funkcję głowy państwa de facto sprawowało - mające kolegialną postać - Prezydium Krajowej Rady Narodowej ${ }^{3}$. Wprawdzie nie mówił o tym wprost żaden przepis prawa, ale podobny wniosek wypływał z obserwacji praktyki ustrojowej działania najwyższych władz państwowych. Nie była to jednak praktyka przypadkowa. Przyjęcie takiego rozwiązania w kręgach ówczesnego politycznego establishmentu stanowiło wyraźne nawiązanie do wzorca sowieckiego, a konkretnie do trzech kolejnych sowieckich konstytucji, w których zerwano z konstrukcją prezydentury monokratycznej, zastępując ją instytucją wieloosobową ${ }^{4}$.

${ }^{1}$ Manifest PKWN stwierdzał: „Dlatego Krajowa Rada Narodowa, tymczasowy parlament narodu polskiego, powołała Polski Komitet Wyzwolenia Narodowego..."; z kolei ustawa z 21 lipca 1947 r. o utworzeniu Polskiego Komitetu Wyzwolenia Narodowego stwierdzała: „Rozpoczęły się decydujące walki o wypędzenie z Polski niemieckich najeźdźców. W obliczu tych historycznych wydarzeń Krajowa Rada Narodowa powołuje Polski Komitet Wyzwolenia Narodowego jako tymczasową władzę wykonawczą dla kierowania [...]”.

${ }^{2}$ W pierwotnym tekście ustawy była mowa o przewodniczącym Krajowej Rady Narodowej (ustawa z dnia 11 września 1944 r. o kompetencji Przewodniczącego Krajowej Rady Narodowej, Dz. U. RP Nr 5, poz. 23). Nazwę tego urzędu zmieniono jednak na mocy dokonanej w późniejszym czasie nowelizacji, sięgając po termin Prezydent Krajowej Rady Narodowej (ustawa z dnia 31 grudnia 1944 r. o zmianie ustawy z dnia 11 września 1944 r. o kompetencji Przewodniczącego Krajowej Rady Narodowej, Dz. U. RP. Nr 19 poz. 97).

3 J. Zakrzewska, Organizacja i funkcjonowanie Krajowej Rady Narodowej, [w:] A. Burda (red.), Krajowa Rada Narodowa, Wrocław-Warszawa-Kraków-Gdańsk 1976, s. 175.

${ }^{4}$ Takim organem wedle konstytucji z 1918 r. było Prezydium Centralnego Komitetu Wykonawczego RSFRR, następnie według konstytucji z 1923 r. Prezydium Centralnej Komisji Wykonawczej ZSRR czy wreszcie w świetle konstytucji z 1936 r., Prezydium Rady Najwyższej ZSRR. 
Prezydium miało status organu wewnętrzny ówczesnego parlamentu. Był to twór nieznany polskiemu konstytucjonalizmowi, w tym także tradycji ustrojowej okresu międzywojnia. Swoją podstawę działania wywodziło Prezydium ze Statutu Tymczasowego Rad Narodowych z 1 stycznia 1944 r. ${ }^{5}$, a więc $\mathrm{z}$ aktu ustanowionego jeszcze w okresie okupacji hitlerowskiej. Później kwestię statusu Prezydium uregulowała dodatkowo wspomniana ustawa o organizacji i zakresie działania rad narodowych ${ }^{6}$. Skład Prezydium obejmował od 5 do 7 osób, wybieranych przez Sejm: Przewodniczącego KRN (później określanego mianem Prezydenta KRN), Naczelnego Dowódcy Wojska Polskiego, zastępcy Przewodniczącego oraz pozostałych członków. W gestii Prezydium komunistyczny prawodawca skupił szereg kompetencji, które zasadniczo odnosiły się do dwóch obszarów aktywności, tj. do kierowania pracami Krajowej Rady Narodowej oraz do zastępowania jej w okresie, gdy posłowie nie obradowali ${ }^{7}$. Prezydium nie nabyło natomiast - jak już była o tym mowa - formalnych uprawnień głowy państwa. Funkcja ta stanowiła jedynie pochodną pozycji, jaką Prezydium uzyskało w nowej rzeczywistości politycznej $^{8}$ i wynikała z konieczności wypełnienia luki prawnej związanej z tymczasowym brakiem rozwiązań instytucjonalnych ${ }^{9}$. Fakt, że w omawianym okresie nie obowiązywały żadne przepisy, wskazujące expressis verbis na wyodrębnienie $\mathrm{w}$ konstytucyjnych systemie władz urzędu prezydenta, nie oznaczał, że w ogóle nie dało się znaleźć normatywnej podstawy dla działania tego organu. Otóż pewne znaczenie miały tu - odnotujmy na marginesie - te postanowienia Statutu (powtórzone notabene w Manifeście Lipcowym), które wprowadzały zasadę, że ustrój nowo tworzonego państwa oparty jest na „podstawowych założeniach” konstytucji międzywojennej z 1921 r. Ich treść nasuwała bowiem wniosek, iż władza ludowa godzi się na recepcję do porządku konstytucyjnego podstawowych urządzeń państwowych z czasów międzywojennej demokracji parlamentarnej, w tym również instytucji głowy państwa. Pogląd przypisujący „podstawowym założeniom” normatywny cha-

\footnotetext{
${ }^{5}$ Akt ten nie był nigdzie publikowany. Przyjęła go KRN w drodze uchwały z 1 stycznia $1944 \mathrm{r}$.

${ }^{6}$ Prawnoustrojowe stanowisko Prezydium KRN określał art. $13 \S 2$ ustawy w brzmieniu noweli z 6 maja 1945 r.; do czasu uchwalenia ustawy wrześniowej skład Prezydium KRN ustalił art. 5 ust. 1 Statutu Tymczasowego Rad Narodowych.

${ }^{7}$ Szerzej na temat kompetencji Prezydium KRN zob. J. Mordwiłko, Rola i działalność Prezydium Krajowej Rady Narodowej (W XXX rocznicę powstania KRN), „Państwo i Prawo”, z. I, 1974, s. 7 i nast.

${ }^{8} \mathrm{~W}$ jego skład wchodzili najwyżej postawieni dygnitarze reżimu. W okresie lipiec 1944 - maj 1945 r. byli to: przewodniczący - B. Bierut (członek Biura Politycznego KC PZPR), wiceprzewodniczący - E. Osóbka-Morawski (premier, przewodniczący CKW PPS), sekretarz - K. Mijał (członek Sekretariatu KC PZPR), członkowie - W. Kowalski, wiceprezes NKW SL, bliski współpracownik B. Bieruta) i M. Żymierski (Naczelny Dowódca WP).

${ }^{9} \mathrm{~W}$ prezydium zasiadali czołowi działacze partyjni tamtego okresu, w tym B. Bierut jako przewodniczący.
} 
rakter był dość popularny w okresie powojennym. Głosili go najwybitniejsi konstytucjonaliści tego czasu z Andrzejem Mycielskim, Stanisławem Rozmarynem, Konstantym Grzybowskim oraz Antonim Peretiatkowiczem na czele ${ }^{10}$. Najdalej w swych twierdzeniach poszedł pierwszy z wymienionych autorów, broniący tezy, że Konstytucja marcowa, wobec brzmienia postanowień Manifestu Lipcowego, obowiązywała przez cały okres prowizorium ustrojowego w wersji literalnej z $1921 \mathrm{r}$. Za punkt wyjścia przyjął on tutaj rozumowanie, że skoro Manifest uznał konstytucję z $1935 \mathrm{r}$. za bezprawną, to wynikał z tego wniosek, iż Konstytucja marcowa nigdy nie została legalnie uchylona i obowiązywała nada ${ }^{11}$. Wszelkie natomiast zmiany, jakie prawodawca komunistyczny wprowadził do struktury ustrojowej państwa w analizowanym okresie, w dość niezrozumiały sposób autor tłumaczył tym, że niektóre przepisy Konstytucji marcowej de facto nie obowiązują.

Nieco inaczej na tym tle przedstawiała się teza stawiana mutatis mutandis przez pozostałych autorów. Wszyscy oni w ocenie przedmiotowego zagadnienia stanęli na gruncie zmian społeczno-politycznych, związanych z ukształtowaniem się w powojennej Polsce władzy o rodowodzie rewolucyjnym. Za punkt wyjścia przyjęli rozumowanie, że źródłem legalności powojennego prawodawstwa konstytucyjnego nie jest koncepcja ciągłości państwa, lecz wola nowych rządzących. Przy takim założeniu regulacje zawarte w Konstytucji marcowej miały odgrywać pewną pragmatyczną rolę, umożliwiając prawidłowe funkcjonowanie systemu ustrojowego Polski Ludowej. O zakresie ich obowiązywania decydowała jednak ostatecznie nowa władza. „Nie z Konstytucji Marcowej czerpała swoją władzę prawną Krajowa Rada Narodowa, ale, przeciwnie, podstawowe założenia Konstytucji uznane zostały za obowiązujące na skutek decyzji Krajowej Rady Narodowej i Manifestu Lipcowego", pisał dobitnie A. Peretiatkowicz ${ }^{12}$, tłumacząc tym samym powody, dla których w jego uznaniu Krajowa Rada Narodowa miała prawo do formułowania autentycznej wykładni podstawowych ustawy zasadniczej z $1921 \mathrm{r}$. W podobnym tonie wypowiadał się S. Rozmaryn, podkreślający, że „KRN była jedynym źródłem legalnej władzy w Polsce i tymczasowym parlamentem w odrodzonym państwie - czerpiącym swoją legitymacje z woli szerokich mas"13.

${ }^{10}$ Pogląd ten zyskał akceptację także w późniejszym okresie: W. Skrzydło, Charakter i znaczenie polityczno-prawne Manifestu Lipcowego PKWN, „Czasopismo Prawno-Historyczne”, t. XI 1959, z. 2, s. 3 i nast.; A. Gwiżdż, Manifest Lipcowy i analogiczne akty proklamacyjne władzy ludowej, „Państwo i Prawo”, 1969, nr 7, s. 33 i nast. O kwestii zakresu obowiązywania Konstytucji marcowej oraz o sposobie rozumienia pojęcie ,podstawowych założeń” zob. K. Działocha, J. Trzciński, Zagadnienie obowiazywania Konstytucji Marcowej w Polsce Ludowej 1944-1952, Wrocław-Warszawa-Kraków-Gdańsk 1977, s. 110-131.

${ }^{11}$ A. Mycielski, Polskie prawo polityczne (Konstytucja z 17 III 1921 r.), Wrocław 1947, s. 7.

${ }^{12}$ A. Peretiatkowicz, Konstytucja Marcowa a Konstytucja Lutowa, „Państwo i Prawo”, z. 11 (21)/ /1947, s. 59.

${ }^{13}$ S. Rozmaryn, Polskie prawo państwowe, Warszawa 1951, s. 253. 
Jeszcze ostrzej stawiał sprawę K. Grzybowski, który pisał: „Konstytucja Marcowa obowiązuje nie dlatego, że została nielegalnie uchylona (to jest tylko uzasadnieniem politycznym jej przywrócenia), ale dlatego, że taka jest wola nowych rządzących. Mamy do czynienia z pierwotnym powstaniem nowej władzy, a nie z państwem jej pochodnym, opartym na istniejącym i formalnie obowiązującym (choć gwałtem usuniętym) porządku prawnym. Mamy do czynienia z rewolucyjną, a nie formalnie legalną genezą nowej władzy" ${ }^{14}$. Pogląd ten nabiera dla nas szczególnego znaczenia, jeśli skonfrontujemy go z inną, wygłoszoną w odrębnej publikacji tezą, w której K. Grzybowski jednoznacznie opowiada się za tym, by w poczet ,podstawowych założeń” Konstytucji marcowej zaliczyć instytucję prezydenta ${ }^{15}$.

II. Jak już była o tym mowa, prezydentura w Polsce Ludowej przywrócona została z mocy ustawy z 11 września 1944 r. o kompetencji Przewodniczącego Krajowej Rady Narodowej, od 31 grudnia 1944 r. noszącego tytuł Prezydenta Krajowej Rady Narodowej. Komunistyczny ustrojodawca przyjął w tym zakresie dość karkołomną konstrukcję prawną, polegającą na tym, że restytuowany urząd głowy państwa uznano ex lege za opróżniony i wzorem rozwiązań Konstytucji marcowej przekazano zastępstwo przewodniczącemu ówczesnego parlamentu. Wynikało to z dwóch pierwszych artykułów przywołanego aktu normatywnego. W art. 1 prawodawca zawarł postanowienie, w myśl którego prezydentowi Krajowej Rady Narodowej przysługiwały wszystkie uprawnienia marszałka Sejmu. Z kolei w art. 2 stwierdzał, iż wobec opróżnienia urzędu Prezydenta Rzeczypospolitej Polskiej, zastępował go prezydent Krajowej Rady Narodowej.

Narzuca się w tym miejscu pytanie o to, dlaczego komunistyczny prawodawca, tworząc urząd Prezydenta, nie uczynił tego wprost, bez odwoływania się do rozwiązań statuujących zastępstwo. W dostępnych źródłach nie sposób natrafić na jednoznaczną eksplikację. Charakterystycznie przedstawia się tu treść sprawozdania stenograficznego KRN z 9 i 11 września 1944 r., który w odniesieniu do prac prowadzonych przez Radę w zakresie analizowanych przepisów stwierdza krótko, że ,przeciw ustawie o kompetencji Przewodniczącego KRN zastrzeżeń nie podniesiono"16. Także w literaturze przedmiotu żaden z przedstawicieli nauki prawa konstytucyjnego nie podejmuje próby wyjaśnienia tego fenomenu, przechodząc nad problemem do porządku dziennego. W efekcie skazani jesteśmy na domysły, które jednak pozostawiają niedosyt i wymagają weryfikacji ze strony historyków. Wydaje się bowiem, że o kształcie instytucji prezydenta $\mathrm{w}$ omawianym okresie zadecydowały nie

${ }^{14}$ K. Grzybowski, Ustrój polski wspótczesnej 1944-1948, Kraków 1948, s. 200, przyp. 5.

${ }^{15}$ Idem, Ustrój polityczny Polski, [w:] Zarys historyczno-polityczny I-go rzadu demokratycznego w Polsce 1944-1946, K. Grzybowski (red.), Warszawa 1947, s. 29-30.

${ }^{16}$ Spraw. sten. z posiedzenia KRN z dnia 9 i 11 września 1944 r., s. 6. 
względy natury prawniczej, lecz osobista pozycja w ówczesnym aparacie władzy szefa Krajowej Rady Narodowej Bolesława Bieruta.

Wprowadzenie do porządku konstytucyjnego instytucji jednoosobowej głowy państwa przy jednoczesnym użyciu funkcji zastępstwa prezydenta siłą rzeczy musiało wywoływać skojarzenia ze stanem prawnym okresu międzywojennego. Prawodawca i w jednym, i w drugim przypadku posłużył się konstrukcjami prawnymi bazującymi na identycznym założeniu, wedle którego głowa państwa $\mathrm{w}$ okresie wakowania urzędu miała być zastępowana przez szefa legislatywy. Także wykorzystanie Konstytucji marcowej jako podstawy prawnej pozwalało prima facie sądzić, że oba modele są do siebie zbliżone. Były to jednak pozory. Dające się tu zauważyć podobieństwo w gruncie rzeczy dotyczyło wyłącznie zewnętrznych form ustrojowych, w rzeczywistości bowiem między mechanizmem uregulowanym pierwotnie w Konstytucji marcowej a tym, które recypowano w Polsce Ludowej, rysowała się wyraźna różnica. Bliższa analiza przedmiotowego zagadnienia nie pozwala uwolnić się od refleksji, że komunistyczny prawodawca, dążąc do zapełnienia istniejącej luki prawnej nowym rozwiązaniem, wprowadził zupełnie nową jakość. Była to zmiana doniosła, wpływająca nie tylko na kształt samego modelu zastępstwa, ale wywołująca także skutki w odniesieniu do miejsca i roli głowy państwa w strukturze ustrojowej państwa komunistycznego działającego w latach 1944-1947.

III. Jak wiadomo, funkcję zastępcy prezydenta otrzymał przewodniczący KRN, zwany od grudnia 1944 r. Prezydentem KRN. Organ ten istniał od samego początku działania KRN. Obowiązujący jeszcze w okresie okupacji Statut Tymczasowych Rad Narodowych prawie w ogóle nie zajmował się jego pozycją ustrojową. Zawierał wyłącznie wzmiankę, w myśl której KRN wybierała pięcioosobowe prezydium z przewodniczącym na czele. Regulacja ta oznaczała, iż przewodniczący ma być szefem parlamentu. Szczególną rolę w ukształtowaniu stanowiska przewodniczącego odegrało dopiero ustawodawstwo z późniejszego okresu, tj. konkretnie uchwalone w dniu 11 września 1944 r. ustawy: ustawa o organizacji i zakresie działania rad narodowych oraz przywołana już ustawa o kompetencji Przewodniczącego (Prezydenta) Krajowej Rady Narodowej. Cechą charakterystyczną przyjętych w obu aktach rozwiązań było wyraźne nawiązanie do przepisów Konstytucji marcowej. Wprowadzono tu zasadę, w świetle której do przewodniczącego KRN i jego zastępców zastosowanie miały wszystkie postanowienia konstytucji z 1921 r. (art. 14 ustawy o radach narodowych), także w dziedzinie zastępstwa Prezydenta Rzeczypospolitej Polskiej (cytowany wcześniej art. 2 ustawy o kompetencjach Przewodniczącego Krajowej Rady Narodowej). Przyjęte założenie nie oznaczało jednak pełnej recepcji uregulowań Konstytucji marcowej. Zwłaszcza gdy idzie o prawną konstrukcję zastępstwa głowy pań- 
stwa w urzędzie, w oczy rzucały się wydatne różnice. Analizując ten problem, J. Zakrzewska zwracała uwagę, że w istocie mieliśmy tu do czynienia jedynie z zastosowaniem zasad Konstytucji z 1921 r., nie zaś z pełnym urzeczywistnieniem zawartych $\mathrm{w}$ niej przepisów ${ }^{17}$.

Pierwsza zasadnicza dystynkcja dotyczyła prawnej regulacji prezydenckiego wakatu. W ustroju przedwojennym stan opróżnienia fotela prezydenckiego miał być z natury rzeczy stanem tymczasowym. Wynikało to $\mathrm{z}$ faktu, że dla ustrojodawcy tamtego okresu wakat, o jakim mowa, stanowił sytuację anormalną, zakłócającą prawidłowe działanie mechanizmu władzy państwowej. Z tego też względu stosowne przepisy wymagały podjęcia przez właściwe organy określonych działań, zmierzających do wyłonienia nowego prezydenta. Jak już sygnalizowałem we wcześniejszych rozważaniach, art. 41 Konstytucji marcowej przewidywał, że w wypadku opróżnienia urzędu głowy państw Zgromadzenie Narodowe zbiera się „,natychmiast” na posiedzenie w celu wyboru następcy. Także gdy prezydent nie mógł sprawować urzędu, mandat marszałka Sejmu do wykonywania funkcji zastępcy rozciągał się zasadniczo na okres nie dłuższy niż 3 miesiące. Po upływie tego terminu, zgodnie z brzmieniem art. 42 Konstytucji, marszałek miał obowiązek zwołać Sejm dla podjęcia uchwały o uznaniu urzędu prezydenta za opróżniony.

Tymczasem temporalne ramy zastępstwa przewodniczącego (prezydenta) KRN określone zostały zgoła odmiennie. Komunistyczny ustrojodawca uznał mianowicie stan wakatu za rzecz pożądaną, wynosząc tym samym przedmiotowe rozwiązanie do rangi zasady konstytucyjnej (art. 2 ustawy o kompetencji prezydenta KRN). Według ustanowionych przepisów, na przewodniczącym (prezydent) KRN ciążyła powinność wykonywania obowiązków głowy państwa przez cały okres aż do momentu ukonstytuowania się parlamentu, który miał być zwołany w bliżej nieokreślonej przyszłości (art. 5 ustawy o kompetencji Prezydenta KRN). Praktyka potwierdziła obowiązywanie tej reguły. Trzymając się norm konstytucyjnych, zwołany 4 lutego 1947 r. Sejm Ustawodawczy, niezwłocznie po ukonstytuowaniu swojego bytu, najpierw uchwalił ustawę konstytucyjną o wyborze Prezydenta Rzeczypospolitej Polskiej ${ }^{18}$, a następnie, jeszcze w tym samym dniu, dokonał obsady urzędu ${ }^{19}$. Z prawnego punktu widzenia oznaczało to wygaśnięcie funkcji zastępcy i scedowanie władzy na rzecz nowo wybranej głowy państwa, choć w praktyce urząd za-

${ }^{17}$ J. Zakrzewska, Organizacja i funkcjonowanie Krajowej Rady Narodowej, [w:] A. Burda (red.), Krajowa..., s. 173.

${ }^{18}$ Ustawa z 4 lutego 1947 r. o wyborze Prezydenta Rzeczypospolitej Polskiej, Dz. U. nr 9, poz. 43.

${ }^{19}$ Co ciekawe, miało to miejsce przed formalnym uchwaleniem ustawy o organizacji i zakresie działania najwyższych organów Rzeczypospolitej, uchodzącej za podstawowy akt regulujący ustrój państwa. Zdaniem S. Rozmaryna kolejność ta świadczyła zarówno o politycznym znaczeniu urzędu głowy państwa, jak i o wielkim autorytecie osoby Prezydenta KRN: S. Rozmaryn, Polskie prawo państwowe, Warszawa 1951, s. 411-412. 
chował personalną ciągłość. Pierwszym - i jedynym - prezydentem państwa polskiego w okresie 1947-1952 został bowiem wcześniejszy Prezydent KRN Bolesław Bierut.

Warto pamiętać, że żaden $\mathrm{z}$ obowiązujących po wojnie przepisów nie regulował kwestii zastępstwa przewodniczącego (prezydenta) KRN. Prawo tego okresu nie przewidywało ani instytucji wiceprezydenta, ani jakiegokolwiek innego rozwiązania. Opierając się na Konstytucji marcowej, można było co najwyżej ustalić przesłanki tymczasowej niezdolności bądź wakowania urzędu, z natury rzeczy jednak odpadało wskazanie per analogiam osoby zastępcy. Problem ten, mimo niewątpliwej doniosłości, nie doczekał się refleksji naukowej. Praktyka życia państwowego nie zrodziła wprawdzie przypadku, w którym podejmowanie podobnych działań stałoby się ustrojową koniecznością, niemniej dylemat z prawniczego punktu widzenia istniał. Akceptując wskazany stan rzeczy, komunistyczne władze utrzymywały poważną lukę prawną, oznaczającą że w razie wystąpienia przeszkody - choćby tymczasowej - w sprawowaniu urzędu przez przewodniczącego (prezydenta) KRN, w określonym czasie de facto przestanie funkcjonować instytucja głowy państwa. Nie załatwiały sprawy regulacje mówiące o zastępcach przewodniczącego (prezydenta) KRN, będących jednocześnie członkami prezydium. Ustawa wrześniowa ograniczała zakres ich działalności do wykonywania kompetencji o charakterze wewnętrznym, związanych zasadniczo z kierowaniem pracami parlamentu. Ich status prawny był analogiczny do statusu, jaki mieli wicemarszałkowie na gruncie uregulowań Konstytucji marcowej. Żaden z nich nie dysponował legitymacją pozwalającą na skuteczne przejęcie prezydenckich obowiązków ${ }^{20}$. Sytuacja wydawała się mniej skomplikowana w momencie powstania w urzędzie wakatu. KRN mogła wówczas zastosować zwykły tryb powołania nowego przewodniczącego i tym samym przy dobrej woli parlamentarzystów szybko usunąć problem. Nie do rozwiązania była natomiast kwestia zaistnienia przeszkody wywołującej potrzebę ustanowienia zastępstwa ad interim. Być może przy takim scenariuszu obowiązki głowy państwa wzięłoby na siebie prezydium KRN, ściśle biorąc pozostali jego członkowie. Jednakże trudno o tym przesądzać, z uwagi na brak jednoznacznych uregulowań prawnych.

Także w dziedzinie posiadanych kompetencji sytuacja prawna Prezydenta KRN różniła się od tej, jaką pod rządami Konstytucji marcowej miał Prezydent Rzeczypospolitej Polskiej. Prawodawstwo komunistyczne nie powieliło w pełnej rozciągłości postanowień swojego międzywojennego pierwowzoru. Analiza porównawcza jednego i drugiego przypadku pozwala ustalić, że powojenny piastun urzędu głowy państwa zasadniczo miał do dyspozycji szczuplejszy zasób kompetencji. Pozornie różnice mogły wydawać się niewielkie,

${ }^{20}$ Wspomina o tym B. Leśnodorski, Parlamentaryzm w Polsce, Kraków 1947, s. 140. 
jakkolwiek $\mathrm{w}$ istocie rzeczy znacząco zmieniały one miejsce prezydentury w systemie konstytucyjnym państwa. Tak się bowiem składa, że odebrane kompetencje należały do rzędu tych, które - patrząc z jurydycznego punktu widzenia - osłabiały pozycję przewodniczącego (prezydenta) KRN w ustrojowych relacjach z parlamentem.

Ograniczenie domeny kompetencyjnej, o jakiej tutaj mowa, wynikało zasadniczo z dwóch przyczyn. Pierwsza wiązała się z tym, że niektóre uprawnienia odpadły jako następstwo odrzucenia Konstytucji marcowej w brzmieniu, jakie ta uzyskała po roku 1926, a więc po przeprowadzeniu zamachu majowego przez popleczników marszałka Józefa Piłsudzkiego ${ }^{21}$. Przyczyna druga natomiast wypływała stąd, iż w wyniku podjętych decyzji prawodawczych, wprowadzających nowe koncepcje w dziedzinie stosunków ustrojowych, część kompetencji właściwych głowie państwa przeszła na rzecz KRN, a część na będące jej wewnętrznym organem prezydium $\mathrm{KRN}^{22}$.

Ustawa o Przewodniczącym (Prezydencie) KRN kompetencje realizowane $\mathrm{z}$ tytułu zastępstwa wymieniała enumeratywnie. W praktyce wszystkie były wykonywane w warunkach rządowej kontrasygnaty ${ }^{23}$. Należały do nich: podpisywanie ustaw wraz z odpowiednimi członkami PKWN i zarządzanie ich ogłoszenia w Dzienniku Ustaw Rzeczypospolitej Polskiej; wydawanie rozporządzeń wykonawczych i zarządzeń; zwierzchnictwo nad siłami zbrojnymi państwa; prawo łaski; reprezentowanie państwa na zewnątrz; przyjmowanie i wysyłanie przedstawicieli dyplomatycznych; zawieranie umów z innymi państwami; mianowanie sędziów oraz nadawanie orderów i odznaczeń, jeżeli ustawa nie stanowiła inaczej. Nieco później, tj. na podstawie ustawy z 31 grudnia 1944 r. o powołaniu Rządy Tymczasowego Rzeczypospolitej Polskiej, katalog ten uzupełniło uprawnienie służące mianowaniu Prezesa Rady Ministrów i na jego wniosek pozostałych członków rządu.

Nie uzyskał prezydent prawa do wydawania rozporządzeń z mocą ustawy. Kompetencja ta w świetle postanowień stosownego aktu normatywnego ${ }^{24}$ stała się udziałem Polskiego Komitetu Wyzwolenia Narodowego, później zaś prze-

${ }^{21}$ F. Siemieński, Ewolucja instytucji Prezydenta Rzeczypospolitej, „Annales Universitatis Marie Curie-Skłodowska", Vol. XXXVII, 13, Sectio G, Lublin 1990, s. 189; zob. także K. Grzybowski, Zarys historyczno-polityczny..., s. 36.

${ }^{22}$ Zob. S. Rozmaryn, Polskie prawo państwowe w okresie Krajowej Rady Narodowej, Łódź 1948, s. 14.

${ }^{23}$ K. Działocha, Problemy rozwoju instytucji prawnoustrojowych w PRL, ,Acta Universitatis Wratislavensis" No 413, Prawo LXXV, s. 25. Kwestia ta nie została uregulowana w prawodawstwie Polski Ludowej, nie licząc szczątkowych unormowań, takich jak art. 4 dekretu PKWN z 2 listopada 1944 r. o organizacji i zakresie działania samorządu terytorialnego, Dz. U. R.P. nr 14, poz. 74, mówiący o kontrasygnacie przewodniczącego PKWN i właściwego kierownika spraw resortu; w tej kwestii zob. bezimienną publikację: Polskie prawo państwowe, część I, Warszawa 1962, s. 75.

${ }^{24}$ Chodzi o ustawę z dnia 15 sierpnia 1944 r. o tymczasowym trybie wydawania dekretów z mocą ustawy, Dz. U. nr 1, poz. 3. 
szła na przekształcony z PKWN Rząd Tymczasowy ${ }^{25}$. Dekrety z mocą ustawy - taką bowiem nazwę nosiły akty prawodawstwa delegowanego w nowym ustroju - dla swej ważności wymagały podpisu przewodniczącego (prezydenta) KRN oraz Przewodniczącego PKWN, a następnie podlegały zatwierdzeniu przez KRN na najbliższym posiedzeniu (art. 1 pkt b wskazanej ustawy).

Podobnie odsunięto od wykonującego funkcję zastępcy prezydenta prawo rozwiązania parlamentu. Restrykcję tę tłumaczyć można w dwojaki sposób. $\mathrm{Z}$ jednej strony przedstawiała się ona jako kontynuacja uregulowań obowiązujących w Konstytucji marcowej, które działającemu w charakterze zastępcy marszałkowi przyznawały pełnię kompetencji prezydenta z wyłączeniem prawa rozwiązania legislatywy. Z drugiej zaś, stanowiła przejaw dezaprobaty komunistycznego prawodawcy dla brzmienia Konstytucji marcowej nadanego prze nowelę kwietniową z roku 1926. Nowelę, która - jak wiadomo - wyposażyła prezydenta w prawo rozwiązywania parlamentu, nieobecne w pierwotnej wersji ustawy zasadniczej. Nie bacząc na źródło wskazanej tutaj normy, podkreślić trzeba, że rozstrzygnięcie tego rodzaju w stworzonym mechanizmie władzy państwowej niosło za sobą złożone konsekwencje. Powodowało ono bowiem, że przewodniczący (prezydent) KRN, z racji trwałości swojej funkcji, możliwości sięgania do wskazanego środka pozbawiony był przez cały okres piastowania stanowiska głowy państwa. Był to jeden z tych elementów nowego ustroju, który nie tylko zmieniał położenie prezydenta $\mathrm{w}$ strukturze organów naczelnych, ale także deformował przyjęty w ramach konstytucji system rządów.

W Polsce Ludowej przewodniczący (prezydent) KRN nie otrzymał kompetencji w postaci zwoływania, zamykania i odraczania sesji parlamentarnych (art. 25 Konstytucji marcowej). Był to niewątpliwy regres w stosunku do koncepcji prezydentury określonej przez przepisy Konstytucji marcowej, wynikający - podobnie jak w przypadku braku prezydenckiej instytucji rozwiązania organu przedstawicielskiego - z odrzucenia w nowym ustroju konstytucyjnym zasady podziału władzy ${ }^{26}$. W ten sposób organy wykonawcze, w szczególności rząd, wyzute zostały z prawnych instrumentów oddziaływania na parlament, będących w każdym przypadku wyrazem istnienia systemu wzajemnego „hamowania się władz"27. Miejsce przedwojennego prezydenta w wykonywaniu wskazanych kompetencji zajęło natomiast prezydium KRN. Obok tego prezydium uzyskało jeszcze prawo do nadawania określonych orderów i odznaczeń.

Poza sferą kompetencji przewodniczącego (prezydenta) KRN znalazły się, wreszcie, kompetencje związane z wprowadzaniem stanu wyjątkowego i wojennego. Decyzje w tych sprawach przekazane zostały KRN.

${ }^{25}$ Zob. F. Siemieński, Prawo konstytucyjne, Warszawa-Poznań 1980, s. 49.

${ }^{26}$ J. Stembrowicz, Z problematyki glowy państwa w Polsce, ,Kultura i Społeczeństwo”, Tom XX, Warszawa 1976, s. 48.

${ }^{27}$ Z. Jarosz, J. Zakrzewska, Krajowa..., s. 77. 
IV. Jedną z najbardziej charakterystycznych cech rozwiązań przyjętych w czasach powojennych była możliwość odwołania przez KRN jej przewodniczącego (prezydenta). Uchwała w tej sprawie pociągała za sobą skutki szczególne, nie tylko bowiem oznaczała odwołanie szefa parlamentu z zajmowanej funkcji, ale powodowała także utratę przezeń atrybutów władzy głowy państwa. Wiadomo, że pod rządami Konstytucji marcowej stanowisko ustrojowe prezydenta prezentowało się zgoła odmiennie. Prezydent, wybierany przez Zgromadzenie Narodowe na okres siedmioletniej kadencji, swój mandat miał sprawować do czasu jej upływu i tylko okoliczność skutkująca wakatem mogła stanąć temu na przeszkodzie. Parlament nie był w stanie go odwołać, choćby nawet na parlamentarnym forum zmieniła się konfiguracja sił politycznych.

Jest rzeczą charakterystyczną, że w ustroju Polski powojennej prawodawca nie sformułował zasady politycznej odpowiedzialności głowy państwa wprost. Mechanizm odwołania wynikał natomiast ze stosunku podporządkowania, jaki łączył szefa parlamentu z KRN. Streszczało się to w założeniu, w myśl którego Rada mogła odwołać swego przewodniczącego nie dlatego, że pełnił on obowiązki głowy państwa, ale dlatego, że był jej wewnętrznym organem. Naturalnie z ustrojowego punktu widzenia podstawa prawna służąca podjęciu stosownej uchwały nie miała większego znaczenia. Skutki prawne, jakie uchwała ta rodziła, w takim samym stopniu dotyczyły stanowiska przewodniczącego KRN i zastępcy prezydenta.

Brak politycznej niezależności w ustroju konstytucyjnym państwa prezydenta od parlamentu niósł za sobą daleko idące konsekwencje. $Z$ całą pewnością nie sposób oceniać tego rozwiązania w kategoriach subtelnego odejścia od zasad wyrażonych w Konstytucji marcowej. Miało ono w istocie olbrzymi ciężar gatunkowy, powodowało bowiem nie tylko zmianę normatywnej konstrukcji zastępstwa prezydenta w urzędzie, ale wpływało także na jurydyczny charakter funkcjonującego w Polsce Ludowej systemu rządów. Nowa jakość powojennych uregulowań zaznaczyła się głównie w stosunkach egzekutywy i legislatywy. Możliwość odwołania głowy państwa z zajmowanego stanowiska skutkowała de iure odrzuceniem zasady podziału władz oraz zasady rządów parlamentarno-gabinetowych i zastąpieniem ich formułą władzy zwierzchniej KRN.

Problem ten dostrzegano w literaturze przedmiotu. Wskazywano w tym kontekście, iż wyrażona w przepisach dominacja KRN w ustroju konstytucyjnym była tym silniejsza, że Rada mogła również kontrolować rząd ${ }^{28}$. Formy tej kontroli nie były nadto rozbudowane, jakkolwiek obejmowały prawo uchwalenia wotum nieufności wobec rządu. Z prawniczego punktu widzenia powstała swoista konstrukcja ustrojowa, wyraźnie odstająca od pryncypiów

\footnotetext{
${ }^{28}$ Szerzej na ten temat zob: Z. Jarosz, J. Zakrzewska, Krajowa..., s. 80-81.
} 
Konstytucji marcowej. W sferze założeń normatywnych bliższa była ona systemowi rządów zgromadzenia aniżeli przyjętemu przed wojną systemowi parlamenarno-gabinetowemu. Jednak nie tylko treść przepisów prawnych składała się na oblicze nowego ustroju. W jeszcze większym stopniu stosunki między najwyższymi władzami państwa determinowały uwarunkowania polityczne. Znaczenie miała tu osobista pozycja przewodniczącego KRN Bolesława Bieruta, uchodzącego za lidera ówczesnej sceny politycznej. O wpływie na mechanizmy ustrojowe personalnego połączenia stanowiska szefa legislatywy i stanowiska głowy państwa pisał po wojnie K. Grzybowski. Autor słusznie zauważał, że długotrwałe związanie wskazanych funkcji siłą rzeczy musi wywoływać skutki tak w dziedzinie polityki, jak i w dziedzinie prawa. Wskazywał przy tym na dwa możliwe do urzeczywistnienia warianty. Jeśli - jak podkreślał - osoba taka okaże się osobą słabą, pozbawioną autorytetu w parlamencie, wówczas jej pozycja musi ulec ustrojowej marginalizacji. Nieuchronnie będzie to prowadzić do zbliżenia formuły rządów w kierunku systemu parlamentarno-gabinetowego, gdzie stanowisko głowy państwa ma bardziej reprezentacyjny charakter. Jeśli jednak osoba ta będzie miała pewną charyzmę i przez swój autorytet zyskać sobie uznanie wśród parlamentarzystów, to automatycznie dojdzie również do jej wzmocnienia w hierarchii władz państwowych. Podobny scenariusz prowadzi do uczynienia z głowy państwa faktycznego kierownika całego aparatu państwa, dysponującego realną władzą, a nie prezydenta o stanowisku typowym dla rządów parlamentarnych, który „panuje, ale nie rządzi”. Krótko mówiąc, „ta sama konstrukcja może przy różnych charakterach piastuna władzy i przy różnym jego faktycznym stosunku do parlamentu dać zupełnie różne rezultaty"29.

$*$

Nie ulega wątpliwości, że przyjęty w okresie powojennego prowizorium ustrojowego model prezydentury odznaczał się daleko idącą specyfiką. Z jurydycznego punktu widzenia była to konstrukcja tyleż oryginalna, co dziwaczna, łącząca w sobie elementy dwóch odrębnych (choć wzajemnie powiązanych) instytucji prawnych. Nie mieściła się w żadnym kanonie myśli konstytucyjnej, a już na pewno wyraźnie odstawała od zasad systemu parlamentarno-gabinetowego, do którego - jak można sądzić - komunistyczny ustrojodawca nawiązywał. Przy analizie i ocenie sygnalizowanych rozwiązań prawnych nie można jednak zapominać, iż były one ustanawiane w szczególnie newralgicznym dla Polski okresie. Jest rzeczą oczywistą, że o konstrukcji władzy państwowej w powojennym porządku ustrojowym przede wszystkim decydowały względy natury politycznej. Komunistyczny prawodawca przy-

${ }^{29}$ K. Grzybowski, Ustrój Polski..., s. 40. 
jął rozwiązania, które odpowiadały istniejącemu stosunkowi sił, sankcjonując przy tym niekwestionowane przywództwo Bolesława Bieruta. W ten sposób pod pozorem demokratycznych form ustrojowych, związanych jeszcze z czasami Polski niepodległej, ukryto rzeczywisty mechanizm sprawowania władzy państwowej, opierający się na inspirowanej przez ZSRR dyktaturze. 
